\title{
Zgrzewanie rezystancyjne punktowe z pneumatycznym i serwomechanicznym dociskiem elektrod
}

\author{
Spot Resistance Welding with Pneumatic \\ and Servomechanical Electrode Force
}

\section{Streszczenie}

W artykule porównano dwa systemy docisku elektrod zgrzewarki w procesie zgrzewania rezystancyjnego tj. klasyczny pneumatyczny i serwomechaniczny. Porównania dokonano na podstawie pomiarów wielkości charakterystycznych procesu tj.: prądu i napięcia zgrzewania oraz przebiegu siły docisku i przemieszczenia elektrod. Wyznaczano wielkości pochodne prądu i napięcia zgrzewania i analizowano: przebieg mocy chwilowej, rezystancji zastępczej statycznej oraz energii dostarczonej do zgrzeiny. Pomiary przeprowadzono na zgrzewarce inwertorowej dla technologicznych prób zgrzewania punktowego dwustronnego dla blach gatunku DX53 o grubości $1.5 \mathrm{~mm}$ z ochronną warstwą cynku. Uzyskane wyniki zweryfikowano eksperymentalnie za pomocą badań niszczących tj. statycznej próby rozciągania oraz badań metalograficznych.

Słowa kluczowe: zgrzewanie rezystancyjne, systemy docisku elektrod zgrzewarki, pneumatyczny system docisku, serwomechaniczny system docisku

\section{Abstract}

The article presents the comparison of two electrode force systems applied in resistance welding machines, i.e. pneumatic (i.e. classical) and servomechanical. The comparison was based on measurements of characteristic quantities of the process, i.e. welding current and voltage as well as the force and travel of electrodes. The study involved the determination of derived quantities of welding current and voltage as well as the analyses of momentary power, static slope resistance and energy supplied to the weld. Measurements, involving the use of an inverter welding machine, were performed for technological tests of two-sided spot welding of $1.5 \mathrm{~mm}$ thick DX53 steel sheets provided with protective zinc coatings. The results were verified experimentally in destructive tests, i.e. static tensile tests and metallographic examinations.

Keywords: resistance welding, welding machine electrode force systems, pneumatic force system, servomechanical force system

\section{Wstęp}

Siła docisku elektrod w procesie zgrzewania rezystancyjnego jest parametrem charakterystycznym technologii, która wyróżnia ten proces spośród innych technologii spajania.

Zgrzewanie rezystancyjne jest procesem, w którym głównym źródłem ciepła jest przepływający przez obszar zgrzewania prąd, o odpowiednim przebiegu, w wyniku, czego następuje nagrzanie obszaru styku łączonych elementów metalowych, przy czym ma miejsce silne ich uplastycznienie lub/i stan ciekły. Do uzyskania trwałego połączenia jest wymagany odpowiedni przebieg siły docisku [1].

Jednym ze stosunkowo nowych podzespołów zgrzewarek, który w istotny sposób zmienia i zarazem znacząco usprawnia proces zgrzewania rezystancyjnego jest silnik serwomechaniczny. Nowy system serwomechanicznego docisku elektrod, w porównaniu do klasycznego systemy pneumatycznego, charakteryzuje szereg zalet [2:7]: i) oszczędności czasu wynikającego ze skróceniu cyklu technologicznego, ii) eliminacja niepożądanych dynamicznych uderzeń elektrody o materiał zgrzewany, iii) zwiększenie trwałości elektrod i brak deformacji roboczych części elektrod, iv) brak deformacji materiału zgrzewanego na początku zgrzewania, v) zredukowanie natężenie hałasu, vi) brak konieczności stosowania instalacji sprężonego powierza.

Zastosowanie systemu serwomechanicznego docisku, z uwagi na odmienny niż klasyczny system pneumatyczny, zmienia $w$ istotny sposób przebieg procesu. Różnice pomiędzy dwoma systemami docisku (pneumatyczny i serwomechaniczny) przedstawiono dla technologii zgrzewania punktowego dwustronnego na podstawie pomiaru wielkości charakterystycznych procesu takich jak: i) przebieg mocy, ii) przebieg rezystancji zastępczej statycznej, iii) energii dostarczonej do zgrzeiny, iv) przebieg siły docisku i przemieszczenia elektrod.

Dr inż. Zygmunt Mikno, mgr inż. Szymon Kowieski - Instytut Spawalnictwa.

Autor korespondencyjny/Corresponding author. zygmunt.mikno@is.gliwice.pl 


\section{System pneumatycznego docisku}

Na zgrzewarce z pneumatycznym system docisku przeprowadzono serię technologicznych prób zgrzewania celem wyznaczenia referencyjnej grupy przebiegów względem których porównywano wyniki uzyskane dla systemu serwomechanicznego docisku. Wybranym reprezentatywnym przebiegiem, dla systemu pneumatycznego docisku, jest przebieg P1 (2) (tablica I, wiersz 2).

Parametry technologii zgrzewania dla blach gatunku DX53 i grubości $1.5 \mathrm{~mm}$ z ochronną warstwą cynku dobrano na podstawie doświadczeń autorów oraz publikacji [1][8][9]. Wyniki dla tej technologicznej próby zgrzewania (P1(2)) stanowiły analizowany wariant odniesienia $\mathrm{nr} 1$ o parametrach przedstawionych poniżej:

- wariant 1 - parametry (tablica I, wiersz 1 $\div 4$, kolumna:

i) $\mathrm{D}-\mathrm{F}_{\text {zadana }}=270 \mathrm{daN}$, ii) $\mathrm{G}-\mathrm{F}_{\text {początkowe }}=270 \mathrm{daN}$, iii) $\mathrm{B}-\mathrm{i}_{\text {zgrz }}$ $=9.5 \mathrm{kA}$, iv) $\mathrm{C}-\mathrm{t}_{\mathrm{zgrz}}=220 \mathrm{~ms}$ ).
$\mathrm{Na}$ kolejnych rysunkach, dla systemu pneumatycznego docisku, przedstawiono odpowiednio:

- rysunek 1 - przebieg siły docisku elektrod i prądu zgrzewania (wariant 1),

- rysunek 2 - przebieg siły docisku elektrod i prądu zgrzewania (powiększenie z rysunku 1).

- rysunek 3 - przebieg prądu zgrzewania (wariant 1),

- rysunek 4 - przebieg rezystancji zastępczej statycznej (wariant 1),

- rysunek 5 - przebieg mocy chwilowej (wariant 1),

- rysunek 6 - przebieg przemieszczenia elektrod (wariant 1).

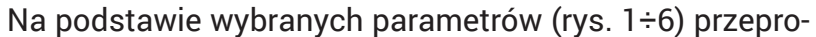
wadzona została analiz porównawcza dla dwóch systemów docisku.

W podsumowaniu wyników pomiaru parametrów dla systemu pneumatycznego docisku (wariant 1) należy zwrócić uwagę na rzeczywisty przebieg siły docisku. Wartość siły docisku jest różna na początku i na końcu przepływu prądu zgrzewania. Wartość siły docisku na początku zgrzewania

Tablica I. Parametry technologii zgrzewania i parametry charakterystyczne dla systemu pneumatycznego i serwomechanicznego docisku elektrod zgrzewarki

Table I. Welding technology parameters and parameters characteristic of the pneumatic and of the servomechanical electrode force system

\begin{tabular}{|c|c|c|c|c|c|c|c|c|c|c|c|c|}
\hline \multicolumn{13}{|c|}{ system PNEUMATYCZNEGO odcisku } \\
\hline \multirow{2}{*}{ L.p. } & \multirow{2}{*}{ nr serii } & \multirow{2}{*}{$\begin{array}{c}\mathrm{I}[\mathrm{kA}] \\
\text { zadane }\end{array}$} & $\mathrm{t}$ & $P_{\text {zadane }}$ & $\mathrm{E}$ & $I_{\text {sk }}$ & $F_{p}$ & $F_{\max }$ & $t_{D W}$ & $\Phi_{j}$ & \multirow{2}{*}{ wariant } & \multirow{2}{*}{ Uwagi } \\
\hline & & & {$[\mathrm{ms}]$} & {$[\mathrm{daN}]$} & {$[\mathrm{kJ}]$} & {$[\mathrm{kA}]$} & [daN] & {$[\mathrm{daN}]$} & [ms] & {$[\mathrm{mm}]$} & & \\
\hline & A & $\mathrm{B}$ & C & $\mathrm{D}$ & $\mathrm{E}$ & $\mathrm{F}$ & G & $\mathrm{H}$ & I & $\mathrm{J}$ & K & $\mathrm{L}$ \\
\hline 1 & \multirow{3}{*}{ P1 } & 9,5 & 220 & 270 & 2,31 & 9,58 & 272 & 330 & 1000 & 5,8 & \multirow{4}{*}{1} & \multirow{4}{*}{$\mathrm{T}_{\mathrm{DW}}=1000 \mathrm{~ms}\left(\mathrm{P} 1 \_2\right)$} \\
\hline 2 & & 9,5 & 220 & 270 & 1,98 & 9,56 & 270 & 324 & 1000 & 6,0 & & \\
\hline 3 & & 9,5 & 220 & 270 & 2,01 & 9,57 & 267 & 301 & 1000 & 5,9 & & \\
\hline 4 & & & & & 2,1 & & 270 & & & 5,9 & & \\
\hline \multicolumn{13}{|c|}{ system SERWOMECHANICZNEGO docisku } \\
\hline \multirow{2}{*}{ L.p. } & \multirow{2}{*}{ nr serii } & \multirow{2}{*}{$\begin{array}{c}\mathrm{I}[\mathrm{kA}] \\
\text { zadane }\end{array}$} & $\mathrm{t}$ & $P_{\text {zadane }}$ & E & $I_{s k}$ & $F_{p}$ & $F_{\max }$ & $t_{D W}$ & $\Phi_{\mathrm{j}}$ & \multirow{2}{*}{ wariant } & \multirow{2}{*}{ Uwagi } \\
\hline & & & {$[\mathrm{ms}]$} & [daN] & {$[\mathrm{kJ}]$} & {$[\mathrm{kA}]$} & {$[\mathrm{daN}]$} & [daN] & {$[\mathrm{ms}]$} & {$[\mathrm{mm}]$} & & \\
\hline 8 & \multirow{3}{*}{$\mathrm{S} 3,+0 \% \mathrm{P} 1$} & 9,5 & 220 & 300 & 1,8 & 9,34 & 269 & 360 & 400 & 3,9 & \multirow{4}{*}{2} & \multirow{4}{*}{$P=-0 \%$} \\
\hline 9 & & 9,5 & 220 & 300 & 2,02 & 9,61 & 271 & 370 & 400 & 4,5 & & \\
\hline 10 & & 9,5 & 220 & 300 & 1,89 & 9,34 & 269 & 370 & 400 & 4,3 & & \\
\hline 11 & & & & & 1,9 & & 270 & & & 4,2 & & \\
\hline 15 & \multirow{3}{*}{ S5, $-20 \% \mathrm{P} 1$} & 9,5 & 220 & 250 & 2,21 & 9,46 & 219 & 330 & 400 & 5,8 & \multirow{4}{*}{3} & \multirow{4}{*}{$P=-20 \%$} \\
\hline 16 & & 9,5 & 220 & 250 & 2,27 & 9,44 & 220 & 304 & 400 & 5,7 & & \\
\hline 17 & & 9,5 & 220 & 250 & 2,27 & 9,41 & 221 & 304 & 400 & 5,7 & & \\
\hline 18 & & & & & 2,3 & & 220 & & & 5,7 & & \\
\hline 21 & \multirow{3}{*}{$\mathrm{S} 7,+20 \% \mathrm{P} 1$} & 9,5 & 220 & 380 & 1,87 & 9,51 & 352 & 443 & 400 & 3,3 & \multirow{4}{*}{4} & \multirow{4}{*}{$P=+20 \%$} \\
\hline 22 & & 9,5 & 220 & 380 & 1,92 & 9,6 & 251 & 438 & 400 & 3,6 & & \\
\hline 23 & & 9,5 & 220 & 380 & 1,91 & 9,5 & 248 & 450 & 400 & 3,3 & & \\
\hline 24 & & & & & 1,9 & & 350 & & & 3,4 & & \\
\hline \multicolumn{13}{|c|}{ modyfikacja technologii SERWO (modulująca siły docisku) } \\
\hline 29 & \multirow{6}{*}{ S10 } & 9,5 & 220 & $100 / 200$ & 2,65 & 9,96 & 106 & 395 & 400 & 7,0 & \multirow{3}{*}{5} & \multirow{3}{*}{$\begin{array}{l}\text { SERWO } 1 \\
\text { (wyprysk) }\end{array}$} \\
\hline 30 & & 9,5 & 220 & $100 / 200$ & 2,61 & 9,98 & 105 & 390 & 400 & 6,5 & & \\
\hline $30 \mathrm{~b}$ & & & & & 2,6 & & 106 & & & 6,8 & & \\
\hline 31 & & 9,5 & 180 & $100 / 250$ & 2,21 & 9,66 & 106 & 275 & 400 & 6,7 & & \\
\hline 32 & & 9,5 & 180 & $100 / 250$ & 2,27 & 9,68 & 107 & 271 & 400 & 5,8 & 6 & SERWO 2 \\
\hline 33 & & & & & 2,2 & & 107 & & & 6,2 & & \\
\hline
\end{tabular}


wynosi 270 daN i jest to wartość zadana ustawiona na manometrze siłownika. Na zakończenie przepływu prądu wartość siły docisku jest nieco wyższa i wynosi około 320 daN. Wzrost wartości siły docisku o około $15 \%$ wynika z nagrzewania się obszaru zgrzewania i tym samym rozszerzalności termicznej materiału zgrzewanego. Siła docisku elektrod i siła wynikająca z rozszerzalności termicznej (materiałów zgrzewanych) powodują zwiększenie sumarycznej wartość siły (w układzie: materiał zgrzewany - elektroda - siłownik pneumatyczny). System pneumatyczny, z uwagi na sprężysty układ docisku jakim jest poduszka powietrzna cylindra dociskowego, w nieznacznym stopniu równoważy wzrost siły. W efekcie końcowym widoczny jest niewielki wzrost siły. Należy nadmienić, że obserwowane zjawisko jest związane (i zależne) z parametrami zgrzewania tj. wartością prądu i czasem zgrzewania ale również z rodzajem zgrzewanych materiałów, wielkością (masą) siłownika w szczególności tłoka i tłoczyska.

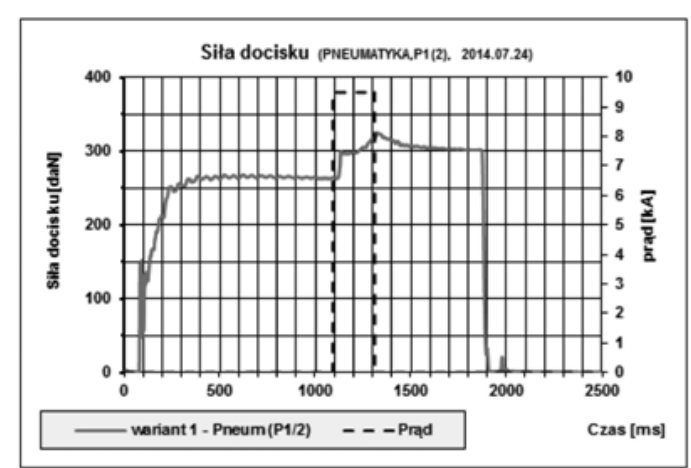

Rys. 1. Przebieg siły docisku elektrod i prądu zgrzewania dla systemu pneumatycznego docisku (wariant 1)

Fig. 1. Course of electrode force and welding current waveform for the pneumatic force system (variant 1)

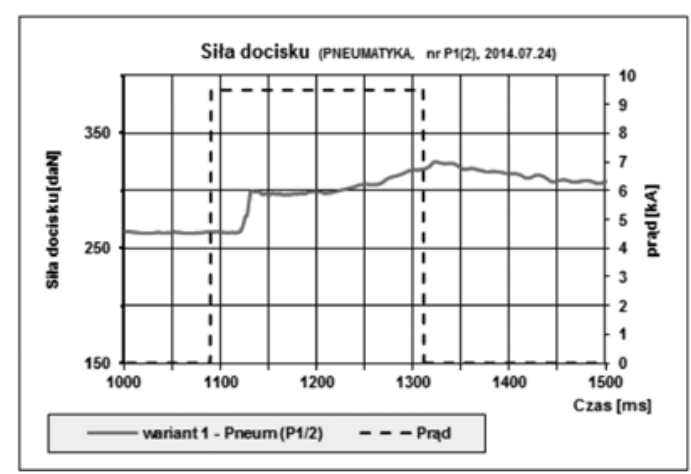

Rys. 2. Przebieg siły docisku elektrod i prądu zgrzewania dla systemu pneumatycznego docisku (powiększenie z rysunku 1)

Fig. 2. Course of electrode force and welding current waveform for the pneumatic force system (magnification from Figure 1)

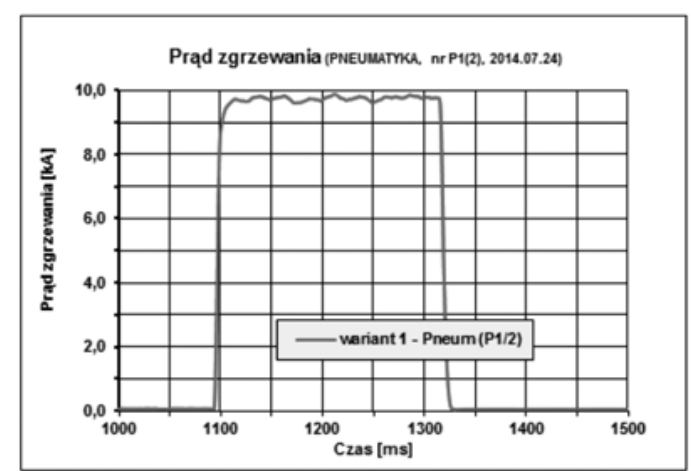

Rys. 3. Przebieg prądu zgrzewania dla systemu pneumatycznego docisku (wariant 1)

Fig. 3. Welding current waveform for the pneumatic force system (variant 1)

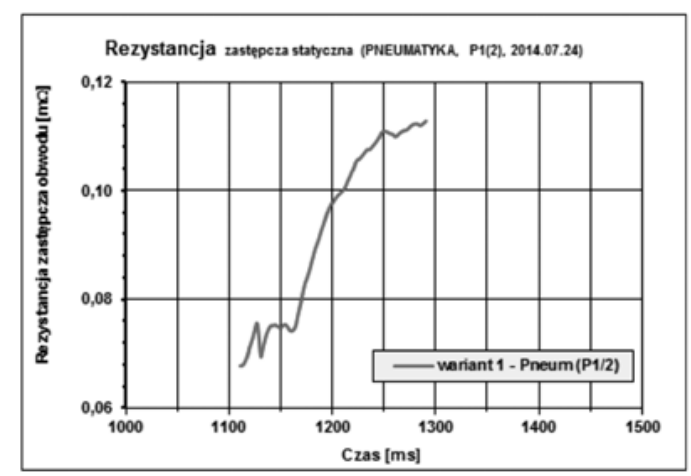

Rys. 4. Przebieg rezystancji zastępczej statycznej dla systemu pneumatycznego docisku (wariant 1 )

Fig. 4. Static slope resistance waveform for the pneumatic force system (variant 1)

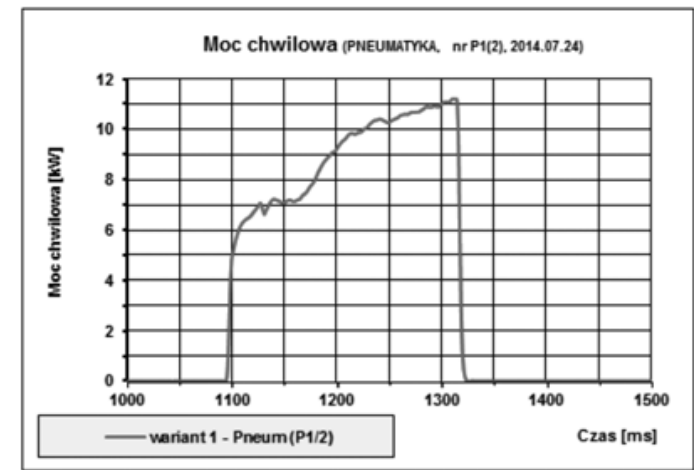

Rys. 5. Przebieg mocy chwilowej dla systemu pneumatycznego docisku (wariant 1)

Fig. 5. Momentary power waveform for the pneumatic force system (variant 1)

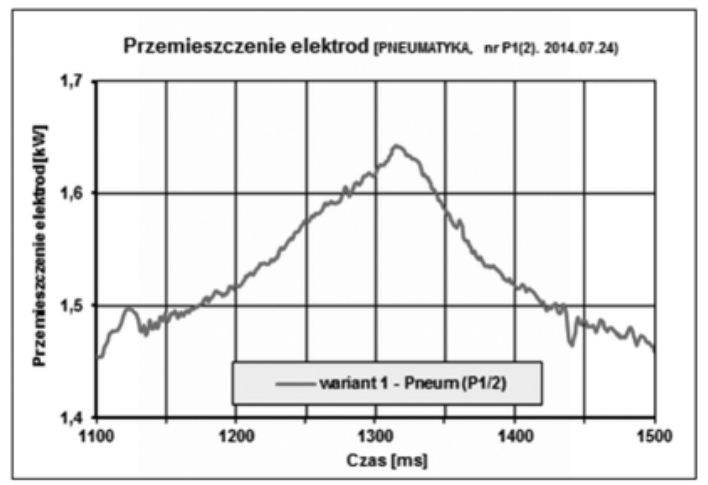

Rys. 6. Przebieg przemieszczenia elektrod dla systemu pneumatycznego docisku (wariant 1)

Fig. 6. Course of electrode travel for the pneumatic force system (variant 1)

\section{System serwomechnicznego docisku}

Dla sprawdzenia działania systemu serwomechanicznego docisku przeprowadzono rozpoznawcze technologiczne próby zgrzewania dla różnych wariantów związanych głównie z przebiegiem siły docisku i jej wartością początkową ale również czasem zgrzewania:

- wariant 2, początkowa siła docisku elektrod równa wartości początkowej jak dla systemu pneumatycznego docisku (tablica I, wiersz 8, 9, 10 i 11, kolumna G - $F_{p}=270$ daN),

- wariant 3, początkowa siła docisku elektrod pomniejszona o około $20 \%$ (-20\%) jak dla systemu pneumatycznego docisku (tablica I, wiersz 15 $\div 18$, kolumna $G-F_{p}=220$ daN),

- wariant 4, początkowa siła docisku elektrod powiększona o około $20 \%$ (+20\%) jak dla systemu pneumatycznego docisku (tablica I, wiersz 21, 22, 23 i 24, kolumna G - $F_{p}=350$ daN), 
Wartości zadane siły docisku (kolumna D dla wariantów $2 \div 4)$ z konieczności były wyższe z uwagi na dynamikę układu dociskowego i uzyskanie założonej początkowej wartości siły docisku elektrod (kolumna G).

- wariant 5:

- początkowa siła docisku elektrod około 30\% wartości nominalnej jak dla systemu pneumatycznego docisku (tablica I, wiersz 29, 30 i 30b, kolumna G - $F_{p}=100$ daN)

- wzrost wartości siły w czasie przepływu prądu do wartości 200 daN (tablica I, kolumna D),

- wariant 6:

- początkowa siła docisku elektrod ok. 30\% wartości jak dla systemu pneumatycznego docisku (tablica I, wiersz 31, 32 i 33, kolumna G - Fp =100 daN),

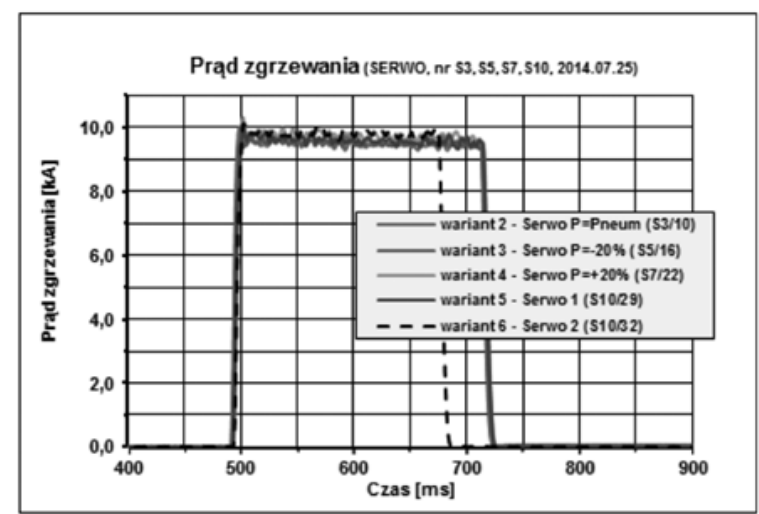

Rys. 7. Przebieg prądu zgrzewania dla różnych wariantów $(2 \div 6)$ dla systemu serwomechanicznego docisku

Fig. 7. Welding current waveform for various variants $(2 \div 6)$ of the servomechanical force system

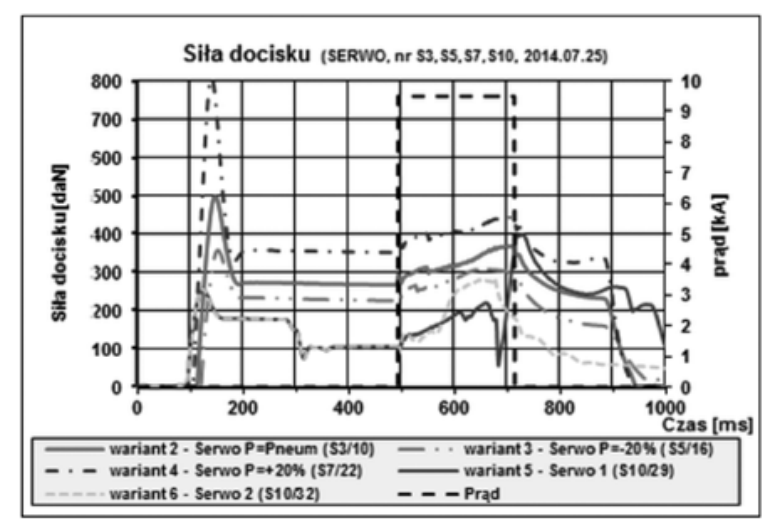

Rys. 8. Przebieg prądu zgrzewania i siły docisku elektrod dla różnych wariantów $(2 \div 6)$ dla systemu serwomechanicznego docisku

Fig. 8. Welding current waveform and course of electrode force for various variants $(2 \div 6)$ of the servomechanical force system

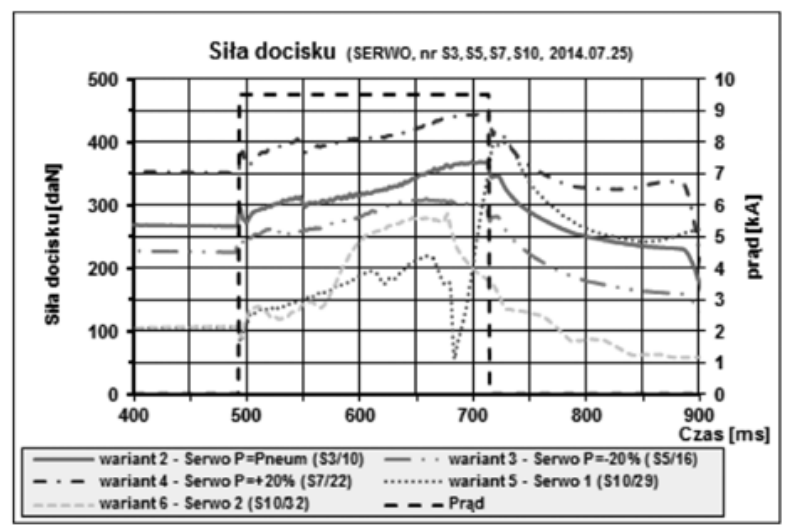

Rys. 9. Przebieg siły docisku elektrod i prądu zgrzewania dla różnych wariantów $(2 \div 6)$ (powiększenie z rysunku 8 )

Fig. 9. Course of electrode force and welding current waveform for various variants of $(2 \div 6)$ (magnification from Figure 8 )
- wzrost wartości siły w czasie przepływu prądu do wartości 250daN (tablica I, kolumna D),

- skrócenie czasu przepływu prądu z 220 do 180 ms (tablica I, kolumna C).

$\mathrm{Na}$ kolejnych rysunkach, dla systemu serwomechanicznego docisku przedstawiono odpowiednio dla różnych analizowanych wariantów $(2 \div 6)$ :

- rys. 7 - przebiegi prądu zgrzewania,

- rys. 8 - przebieg prądu zgrzewania i siły docisku elektrod,

- rys. 9 - przebieg prądu zgrzewania i siły docisku elektrod (powiększenie z rysunku 8).

- rys. 10 - przebiegi rezystancji zastępczej statycznej,

- rys. 11 - przebiegi mocy chwilowej,

- rys. 12 - przebiegi przemieszczenia elektrod.

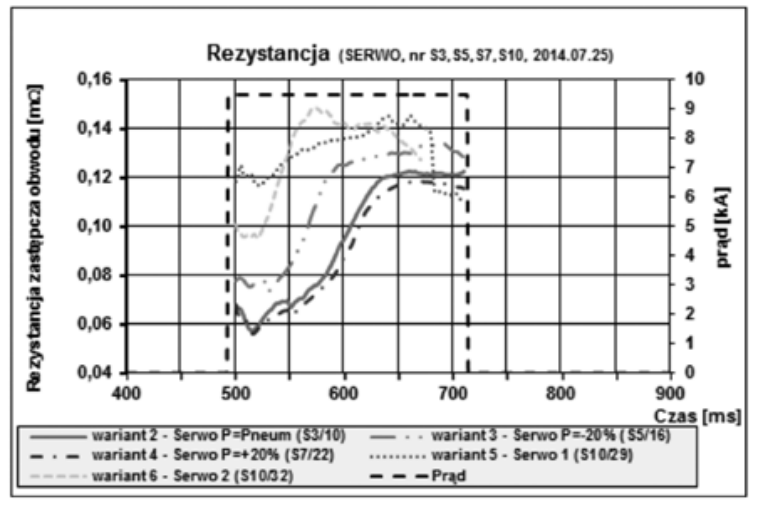

Rys. 10. Przebieg rezystancji zastępczej statycznej dla różnych wariantów $(2 \div 6)$ dla systemu serwomechanicznego docisku

Fig. 10. Static slope resistance waveform for various variants $(2 \div 6)$ of the servomechanical force system

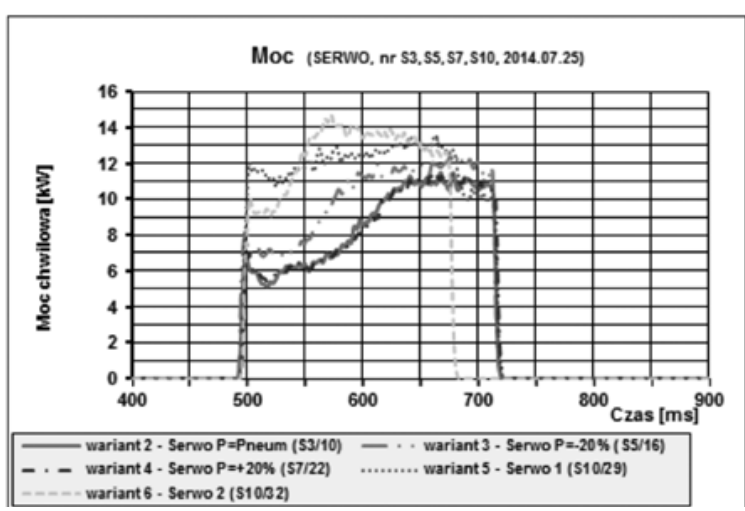

Rys. 11. Przebieg mocy chwilowej dla różnych wariantów $(2 \div 6)$ dla systemu serwomechanicznego docisku

Fig. 11. Momentary power waveform for various variants $(2 \div 6)$ of the servomechanical force system

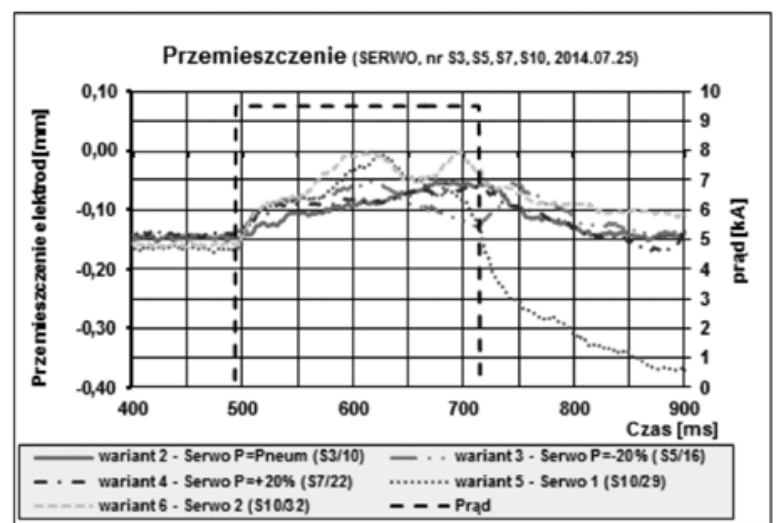

Rys. 12. Przebieg przemieszczenia elektrod dla różnych wariantów $(2 \div 6)$ dla systemu serwomechanicznego docisku

Fig. 12. Course of electrode travel for various variants $(2 \div 6)$ of the servomechanical force system 
W czasie eksperymentów i analizy wyników zaobserwowano dużą zależność uzyskanych wyników (przebiegi rezystancji i mocy, energia) od przebiegu i wartości prądu zgrzewania. Pomimo aktywnej opcji stabilizacji prądu zgrzewania ustawionej w układzie sterowania, obserwowano różnice w wartości prądu zgrzewania na poziomie 200A. Dlatego we wszystkich analizowanych wariantach $(1 \div 6)$, każda z technologicznych próby zgrzewania była dokładnie analizowana z uwzględnieniem wartości prądu zgrzewania (rys. 7).

Rysunek 8 przedstawia przebiegi siły docisku dla analizowanych pięciu wariantów $(2 \div 6)$. Na uwagę zasługuje początkowa (udarowa) wartość siły docisku (t zgrzewania $=100-150 \mathrm{~ms}$ ). Wartość ta wzrasta wraz ze wzrostem nastawianej roboczej siły docisku. Jest to efekt działania algorytmu sterowania silnikiem serwo, którego szybkość dojazdu elektrody uzależniona jest od zadanej wartości siły docisku.

Rysunek 9 przedstawia przebieg siły docisku elektrod i prądu zgrzewania (powiększenie z rysunku 8). Widocznym i zarazem charakterystycznym dla wariantów $2 \div 4$ jest wzrost siły docisku w czasie przepływu prądu zgrzewania. Wartość siły wzrasta o około $30 \%$ (wariant 2 - z 270 daN na 370 daN, wariant $3-$ z 220 daN do 310 daN, wariant 4 - z 350 daN do 450 daN). Jest to charakterystyczna cecha systemów serwo. Układ docisku jest układem sztywnym (zdecydowanie sztywniejszym niż system pneumatyczny) co skutkuje większą wynikową siłą. Efekt ten ma wpływ na przebieg procesu poprzez zmniejszenie rezystancji styków a w konsekwencji obniżenie wartości mocy i tym samym energii dostarczonej do zgrzeiny. W efekcie końcowym uzyskiwane jest jądro zgrzeiny odpowiednio o mniejszych rozmiarach. Dla kolejnych wariantów, wraz ze wzrostem wartości siły docisku, uzyskiwana jest odpowiednio mniejsza średnica jądra zgrzeiny:

- wariant 3, ( $P=$ P pneum -20 \%), $\Phi=5.7$ mm (tablica I, wiersz 15,16 i 17),

- wariant 2, ( $\mathrm{P}=\mathrm{P}$ pneum.), $\Phi=4.2 \mathrm{~mm}$ (tablica I, wiersz 8,9 i 10),

- wariant $4,(P=P$ pneum $+20 \%), \Phi=3.4 \mathrm{~mm}$ (tablica I, wiersz $21 \div 23)$.

Rysunek 10 i 11 przedstawia odpowiednio przebieg rezystancji zastępczej statycznej i przebieg mocy chwilowej. Charakterystyczny jest wzrost rezystancji dla wariantów w kolejności 3,2,4,5 i 6 co wynika ze zmniejszającej się siły docisku, szczególnie na początku procesu zgrzewania. Coraz to większej rezystancji (rys. 10) odpowiada coraz to większa wartość mocy (rys. 11) również dla wariantów w tej samej kolejności 3,2,4,5 i 6.

Technologia z serwomechanicznym dociskiem elektrod została poszerzona o dwa dodatkowe warianty (5 i 6) w których siła docisku na początku wynosiła $30 \%$ wartości nominalnej jak dla pneumatycznego systemu docisku (100 daN). Zdecydowanie mniejsza wartość siły pozwala na uzyskanie większej wartości rezystancji styków w obszarze zgrzewania co widoczne jest na rysunku 10. Z kolei większa wartość rezystancji przy stałym prądzie zgrzewania (stabilizacja prądu) pozwala na uzyskanie (wydzielenie/wygenerowanie) większej mocy zgrzewania (rys. 11). Dla wariantu 5 dla czasu zgrzewania 220 ms (tablica I, wiersz 29, 30, kolumna C) energia zgrzewania była o ok. $2 \%$ wyższa niż dla systemu pneumatycznego docisku. Dla zabiegu polegającego na ustawieniu mniejszej siły docisku spodziewać się można przekroczenia dopuszczalnej mocy chwilowej i w efekcie wyprysku ciekłego metalu. Takie zjawisko zaobserwowano (wariant 5). Jednak dla wyeliminowania niekorzystnego zjawiska jakim jest wyprysk ciekłego metalu skrócono czas zgrzewania (do 180 ms) i zwiększono wartość siły docisku pod koniec czasu przepływu prądu. Wyniki dla wariantu nr 6 przedstawia tablica I (wiersz $31 \div 33$ ). Dla tego wariantu (w porównaniu do pneumatycznego systemu docisku) uzyskano:
- porównywalną wielkość jądra zgrzeiny $\Phi=6.2 \mathrm{~mm}$ (tablica I, kolumna J) (system pneumatyczny $\Phi=5.9 \mathrm{~mm}$ )

- porównywalną energię dostarczoną do zgrzeiny $\mathrm{E}=2.2 \mathrm{~kJ}$ (tablica I, kolumna E) (system pneumatyczny $\mathrm{E}=2.1 \mathrm{~kJ}$ ).

Istotnym jest wprowadzenie w wariancie 5 i 6 modulacji siły docisku. Siła docisku na początku była stosunkowo mała (30\% wartości siły jak dla pneumatycznego docisku) ale w czasie przepływu prądu zgrzewania została ona zwiększona do wartości 200 daN dla wariantu nr. 5 i do wartości 250 daN dla wariantu nr. 6.

Z analizy wyników uwidacznia się kilka zalet systemu serwomechanicznego tj. możliwość zgrzewania w krótszym czasie, możliwość nastawy mniejszego docisku na początku procesu zgrzewania (przepływu prądu) i możliwość modulacji wartości siły docisku w czasie przepływu prądu.

\section{Porównanie systemu pneumatycznego i serwomechanicznego}

Dla porównania systemu pneumatycznego i serwomechanicznego docisku wybrano trzy warianty:

- wariant 1 - system pneumatyczny, parametry (tablica I, wiersz $1 \div 4$, kolumna $G-F_{p}=270$ daN),

- wariant 3 - system serwomechaniczny, zadana (początkowa) siła docisku elektrod pomniejszona o ok. $20 \%$ (-20\%) jak dla systemu pneumatycznego docisku (tablica I, wiersz $15 \div 18$, kolumna $G-F_{p}=220$ daN). Wartość zadana siły docisku jest stała w całym zakresie technologii.

- wariant 6 - system serwomechaniczny:

- początkowa siła docisku elektrod ok. 30\% wartości jak dla systemu pneumatycznego docisku (tablica I, wiersz 31 , 32 i 33, kolumna $G-F_{p}=100$ daN),

- wzrost wartości siły w czasie przepływu prądu do wartości 250 daN (tablica I, kolumna D). Następuje modulacja siły docisku.

- skrócenie czasu przepływu prądu z 220 do 180 ms (tablica I, kolumna C).

Na kolejnych rysunkach, dla porównania systemu pneumatycznego z serwomechanicznym dociskiem przedstawiono odpowiednio dla różnych analizowanych wariantów (1,3 i 6):

- rysunek 13 - przebieg prądu zgrzewania,

- rysunek 14 - przebieg prądu zgrzewania i siły docisku elektrod,

- rysunek 15 - przebieg siły docisku elektrod i prądu zgrzewania (powiększenie z rysunku 14).

- rysunek 16 - przebieg rezystancji zastępczej statycznej,

- rysunek 17 - przebieg mocy chwilowej,

- rysunek 18 - przebieg przemieszczenia elektrod.

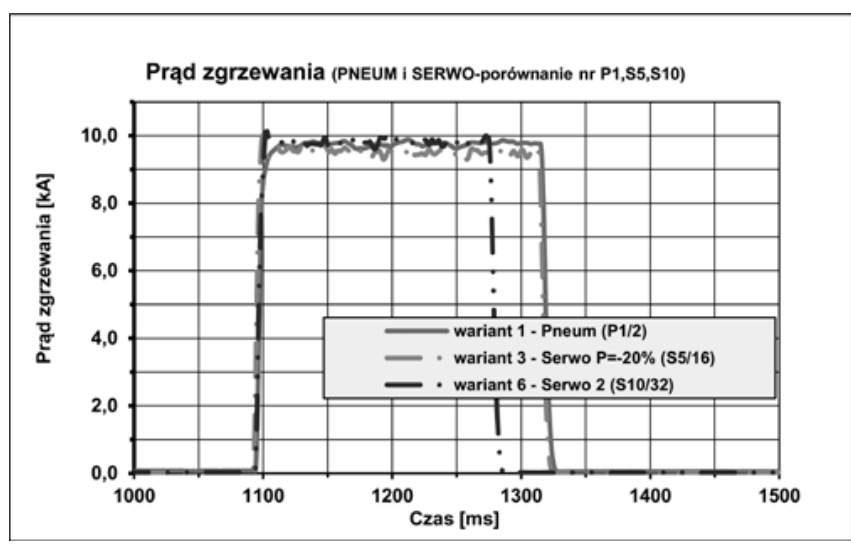

Rys. 13. Przebieg prądu zgrzewania dla systemu pneumatycznego docisku (wariant 1) i serwomechanicznego docisku (wariant 1, 3 i 6) Fig. 13. Welding current waveform for the pneumatic force system (variant 1) and the servomechanical force system (variant 1, 3 and 6) 


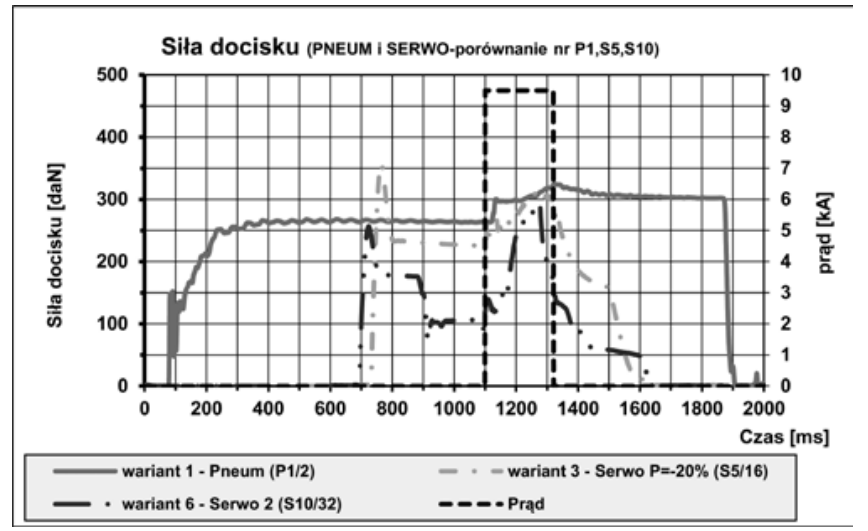

Rys. 14. Przebieg prądu zgrzewania i siły docisku elektrod dla systemu pneumatycznego docisku (wariant 1) i serwomechanicznego docisku (wariant 1, 3 i 6 )

Fig. 14. Welding current waveform and the course of electrode force for the pneumatic force system (variant 1 ) and the servomechanical force system (variant 1, 3 and 6)

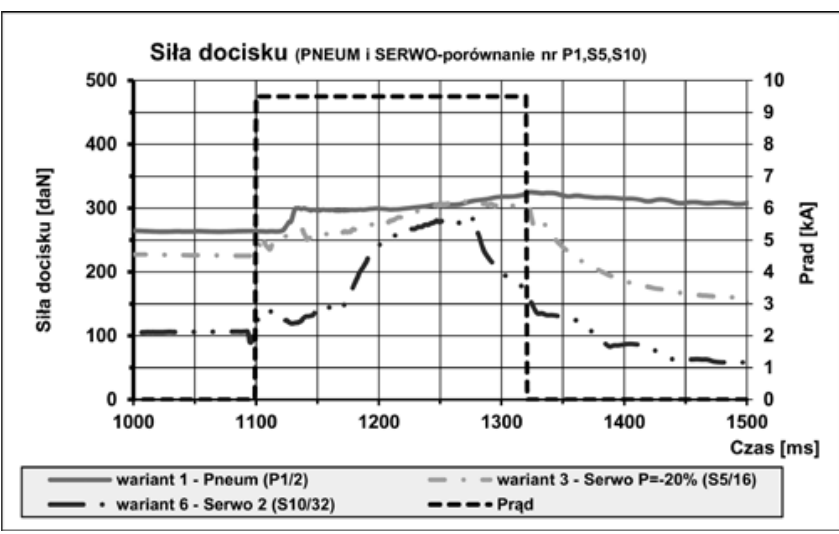

Rys. 15. Przebieg prądu zgrzewania i siły docisku elektrod dla systemu pneumatycznego docisku (wariant 1 ) i serwomechanicznego docisku (wariant 1, 3 i 6) (powiększenie z rysunku 14)

Fig. 15. Welding current waveform and the course of electrode force for the pneumatic force system (variant 1) and the servomechanical force system (variant 1, 3 and 6) (magnification from Figure 14)

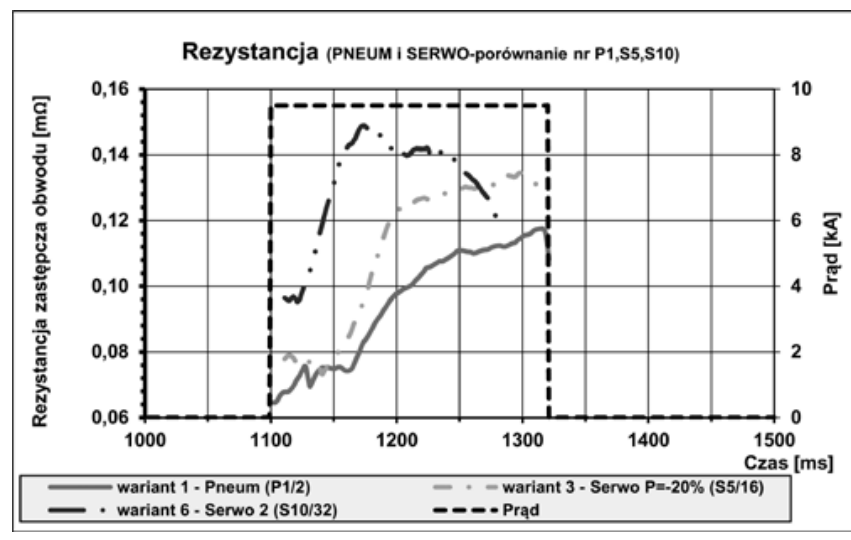

Rys. 16. Przebieg prądu zgrzewania i rezystancji zastępczej statycznej dla systemu pneumatycznego docisku (wariant 1) i serwomechanicznego docisku (wariant 1,3 i 6 )

Fig. 16. Welding current waveform and static slope resistance waveform for the pneumatic force system (variant 1 ) and the servomechanical force system (variant 1, 3 and 6)

Dla pomniejszonej siły docisku o $20 \%$ dla serwomechanicznego docisku (wariant 3) w porównaniu do systemu pneumatycznego (wariant 1) uzyskujemy podobny wynik w postaci wielkości jądra zgrzeiny $(\phi=5.7 \mathrm{~mm}$ - wariant 3 , $\Phi=5.9 \mathrm{~mm}$ - wariant 1, tablica I, kolumna J) i energii dostarczonej do zgrzeiny $(E=2.3 \mathrm{~kJ}$ - wariant $3, E=2.1 \mathrm{~kJ}$ - wariant 1, tablica I, kolumna E). Na taki wynik ma wpływ przebiegi siły docisku dla systemu serwomechanicznego wariant 3 (rys. 15), który można określić jako zbliżony do systemu pneumatycznego (wariant 1). Również podobny (nieznacznie wyższy) co do charakteru przebiegu i wartości jest przebieg rezystancji zastępczej statycznej oraz mocy chwilowej.

Natomiast przemieszczenie elektrod (rys. 18) dla systemu serwomechanicznego (wariant 3), w czasie przepływu prądu zgrzewania, jest o $50 \%$ mniejsze niż dla systemu pneumatycznego docisku (1). Może to mieć istotny wpływ na przebieg procesu zgrzewania. Zjawisko to wymaga dalszych badań w tym zakresie.

Siła docisku w przypadku systemu pneumatycznego (rys. 15, wariant 1) jest na stałym poziomie po zaniku przepływu prądu. Dla serwomechanicznego docisku (wariant 3) następuje spadek wartości siły przy stałej nastawie wartości siły, co wynika z pewnej inercji systemu serwomechanicznego. Można jednak skutecznie zwiększyć wartość siły (np. po zaniku prądu) dla uzyskania żądanej wartości np. dla przekuwania zgrzeiny, czego przykładem jest wariant 5 i przedstawiony przebieg siły docisku na rysunku 9.

\section{Weryfikacja eksperymentalna}

Dla przeprowadzonych technologicznych prób zgrzewania dla wariantów 1 i 6 wykonano badania wytrzymałości zgrzein w statycznej próbie rozciągania oraz badania metalograficzne. Wyniki badań wytrzymałościowych zamieszczono w tablicy II, a zdjęcia badań metalograficznych złączy zgrze-

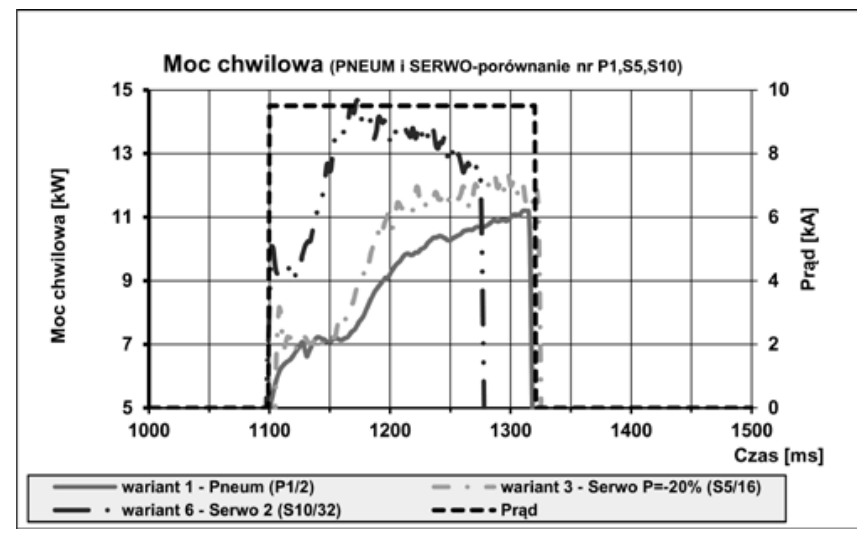

Rys. 17. Przebieg prądu zgrzewania i mocy chwilowej dla systemu pneumatycznego docisku (wariant 1) i serwomechanicznego docisku (wariant 3 i 6 )

Fig. 17. Welding current waveform and momentary power waveform for the pneumatic force system (variant 1) and the servomechanical force system (variant 3 and 6 )

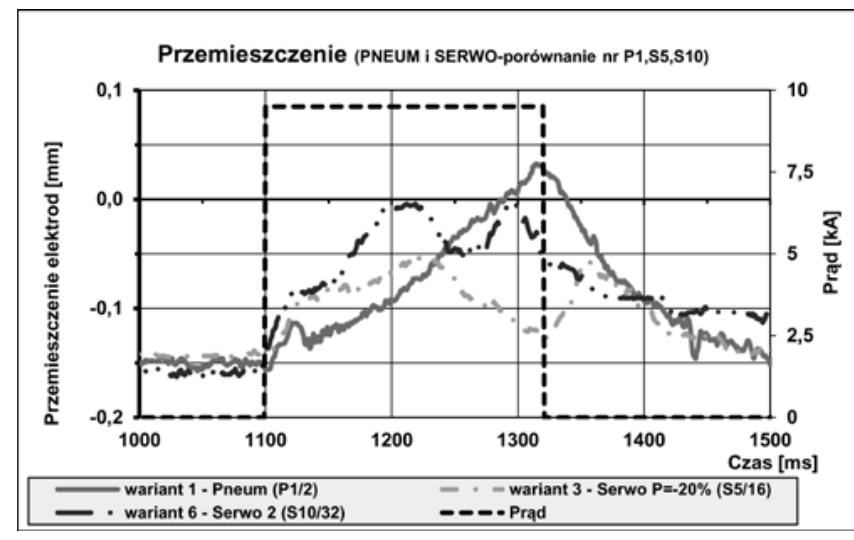

Rys. 18. Przebieg prądu zgrzewani i przemieszczenia elektrod dla systemu pneumatycznego docisku (wariant 1) i serwomechanicznego docisku (wariant 3 i 6 )

Fig. 18. Welding current waveform and the course of electrode travel for the pneumatic force system (variant 1 ) and the servomechanical force system (variant 3 and 6 ) 
wanych przedstawiono na rysunku 19.

Dla analizowanych dwóch wariantów tj. wariant nr 1 (system pneumatyczny, parametry zgrzewania: tablica I wiersz $1 \div 3$ ) i wariantu $\mathrm{nr} 6$ (system serwomechaniczny z modulacją siły docisku, parametry zgrzewania: tablica I, wiersz 31, 32) stwierdzono zbliżone wartości wytrzymałość zgrzein (tablica II). Dla systemu pneumatycznego docisku średnia wytrzymałość złączy zgrzewanych (5 próbek) wynosi 764 daN natomiast dla systemu serwomechanicznego docisku 779 daN. Średnice jądra zgrzeiny w obydwu przypadkach tj. dla systemu pneumatycznego (rys. 19a) i systemu serwomechanicznego (rys. 19b) były takie same i wynosiły $6.0 \mathrm{~mm}$. Badania metalograficzne uwidoczniły również nieznacznie większy wgniot elektrod dla systemu pneumatycznego docisku (rys. 19). Taki wynik jest odzwierciedleniem przemieszczenia elektrod (rys. 18), które jest większe dla wariantu nr 1 (system pneumatyczny) niż dla wariantu nr 6 (system pneumatyczny).

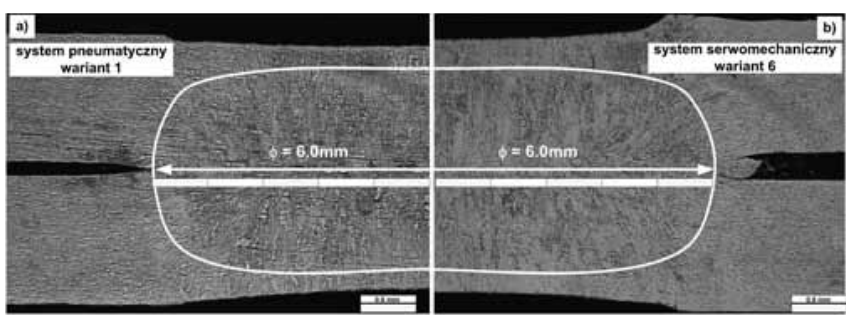

Rys. 19. Struktury metalograficzne zgrzein dla dwóch różnych systemów docisku elektrod (trawienie Nital). a) pneumatyczny - wariant 1 (parametry zgrzewania: tablica I, wiersz 1,2 i 3), b) serwomechaniczny - wariant 6 (parametry zgrzewania: tablica I, wiersz 31,32)

Fig. 19. Metallographic structures of welds for two different electrode force systems (etchant: Nital). a) pneumatic - variant 1 (welding parameters: Table I, line 1,2 and 3), b) servomechanical - variant 6 (welding parameters: Table I, line 31 and 32)

Tablica II. Wyniki badań wytrzymałość zgrzein w statyczne próbie rozciągania

Table II. Results of weld strength tests in static tensile tests

\begin{tabular}{|c|c|c|c|c|c|c|c|}
\hline \multirow{3}{*}{ Wariant } & \multicolumn{6}{|c|}{ Wytrzymałość w statycznej próbie rozciągania } & Średnica jądra zgrzeiny \\
\hline & \multicolumn{6}{|c|}{ daN } & \multirow{2}{*}{$\mathrm{mm}$} \\
\hline & 1 & 2 & 3 & 4 & 5 & średnia & \\
\hline 1 & 785 & 790 & 735 & 735 & 775 & 764 & 6.0 \\
\hline 6 & 770 & 795 & 765 & 775 & 790 & 779 & 6.0 \\
\hline
\end{tabular}

\section{Podsumowanie}

Na podstawie uzyskanych wyników dla systemu pneumatycznego i serwomechanicznego docisku należy zwrócić uwagę na kilka istotnych aspektów:

Podejmując próbę powtórzenia (przełożenia) technologii zgrzewania punktowego wprost z parametrami jak dla systemu pneumatycznego należy pamiętać, że w czasie przepływu prądu zgrzewania wartość siły docisku dla systemu serwomechanicznego docisku wzrasta o około $30 \%$ (rys. 9). Powyższe wymaga nastaw siły docisku o wartości o ok. $20 \%$ niższej niż dla systemu pneumatycznego docisku.

Pozostawienie (przełożenie) tych samych parametrów zgrzewania spowoduje dostarczenie (wydzielenie) mniejszej energii do zgrzeiny i uzyskanie zdecydowanie mniejszej średnicy jądra zgrzeiny (wariant 1 i 2 ).

Serwomechaniczny system docisku umożliwia modulację wartości siły docisku w czasie przepływu prądu zgrzewania (wariant 5 i 6). Pozwala to na ustawienie niższej wartości siły docisku na początku zgrzewania (przepływu prądu), co skutkuje uzyskaniem większej rezystancji w styku i większej mocy zgrzewania. Taki technologiczny zabieg pozwala na wygenerowanie odpowiednio większej mocy w krótszym czasie oraz skrócenie czasu zgrzewania (wariant 6), z zachowaniem stałej wartości najistotniejszego parametru jakim jest średnica jądra zgrzeiny.

Mniejsza siła na początku zgrzewania powoduje mniejsze udarowe uderzenie, co stanowi korzyść z punktu widzenia technologii zgrzewania. Inne zalety wynikające z zastosowania systemu serwomechanicznego to: redukcji hałasu, zwiększenie trwałości elektrod, brak deformacji roboczych części elektrod, brak deformacji materiału zgrzewanego na początku zgrzewania, brak konieczności stosowania instalacji sprężonego powietrza.

Mniejsza siła docisku na początku przepływu prądu powoduje również wydzielanie większej mocy (więcej energii) co korzystnie wpływa na cały proces zgrzewania. Wiąże się to z mniejszą powierzchnią styku elementów zgrzewanych co wpływa na zachowanie odpowiedniej (wysokiej) gęstości prądu zgrzewania.

Wyniki prac badawczych są rozpowszechnianie w ramach projektu TANGO realizowanego latach 2015-2017, finansowanego ze środków Narodowego Centrum Nauki i Narodowego Centrum Badań i Rozwoju.

\section{Literatura}

[1] Klimpel A.: Technologie zgrzewania metali i tworzyw termoplastycznych. Wydawnictwo Politechniki Śląskiej Gliwice 2005.

[2] Zhang X. Q., Chen G. L., Zhang Y. S.: On-line evaluation of electrode wear by servo gun. International Journal of Advanced Manufacturing Technology, Vol 36, 2008.

[3] HongGang Yanga, YanSong Zhanga, XinMin Lai, Guanlong Chena: An experimental investigation on critical specimen sizes of high strength steels DP600 in resistance spot welding. Materials \& Design, Vol 29, no. 9, 2008.

[4] Slavick S. A.: Using serwoguns for automated resistance welding. Welding Journal vol. 78, no7, 1999.
[5] Hana L., Thorntona M., Boomerb D., Shergoldc M.:Effect of aluminium sheet Surface conditions on feasibility and quality of resistance spot welding, Journal of Materials Processing Technology vol. 210, 2010.

[6] Zhang X.Q., Chen G.L., Zhang Y.S.: Characteristics of electrode wear in resistance spot welding dual-phase steels. Materials and Design, vol. 29, 2008.

[7] Mikno Z., Bartnik Z.: Projection welding with pneumatic and servomechanical electrode pressure system in FEM calculation - comparison. The 7th International Seminar on Advances in Resistance WeIding 12-14 September 2012, Busan, Korea. Conferences materials.

[8] Papkala H.: Zgrzewanie oporowe metali, wydawnictwo KaBe Krosno 2003.

[9] Poradnik Inżyniera, Spawalnictwo tom 1, 2 WNT Warszawa 2005. 